\title{
1970 年春季大会俨演要旨
}

\section{仁淀川中・上流地域の地形について}

\author{
古谷 尊彦
}

演者は仁淀川の流域の1/5 万地形図から地形断面と一 般傾斜の分布四を作成し，この流域の3つの部分で地形 に差のあることをみだし，地形断面と一般傾斜分布図に

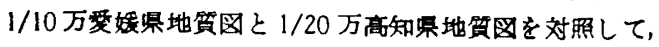
この流域の地形の美が岩石および地筫楼造に制約されて いることを述へた。

主な結果沉放の如くである。

1) 流域の一般的な地形の特欮はいわゆる四国方向に 支配され，ENE-WSW 方向の流路とこれに直角の方向 の流路とからなる。両流路と6浃谷をなしているか，後 者は前者の流路に比してより急蛲な栱谷を形成してい る。横谷部は古生居の一部と御荷睩色岩類および三波 川結晶片岩類からなり，ENE-WSW の方向の地筫楼造 を直角方向に切ること，特に変成岩類については片理方 向に直角の方向の流路である。

2）久万町の爷地は石錦呞群（中新統一鲜新統）の火 山岩類がキ+ッブロックになって，これと下部の三波川 楞の結晶片岩類との間にある久万層群（始新就）の泥贸 分に富む堆稜岩類の部分がより早く侵強された結果形成 された盆地でここの盆地は中村（1963）のいわゆる伴床 谷と同一であると考えられる。

3）重信川の支流久谷川は久万川の延長方向の谷で， いわゆる石鉋断層崖の西への延脣上にあり，中央絊造線 を切って流れ，この部分より河床勾眍か急㑯斜になる。 中央耧造線に沿っては，御坂山地で川䗁 (1959) が述へ た「入」の地形に似の地形を形成している。この部分 の地賀は久万盆地と同棣の関係にある。中央就造線は四 国の中·東部で最近の活動力激しく，久谷川流域につい

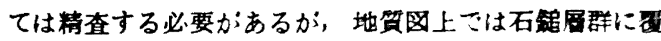
われているから，この部分では断層崖は否定される。

4）仁定川と久谷川の流域の地形は中新繶一鲜新統の

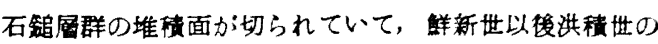
形成になると考えられる。

\section{坟山の開発と関連産業の発远}

㓱箖 実則

本研究では鉣山開発と関連産羍の発達について報告す る。

対象としては，小坂・花岡・阿仁・荒川・院内などの 罢内大規模敛山を選んだ。

明治以降，戦前までの事情は「日本领業誌」「验山要 臨」「各鉱山誌」などの女献によった。累北部の現在碇 行鉱山については現地調査によった。

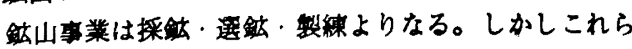
の事業をより円滑に推進させるため，戦前までは製材． 木工・铁工・踭物などの付蓝事莱が盛んに行なわれた。

欲山地域には下請業・組などがみられ，その周辺地域
にボーリング・土建・製材 ·鉄エ · 運送業などの関連産 業が発達する。これはいずれも鉱山業有成のためのもの である。

この他に鉱産物を利用する加工部閒の関連産業があ る。製練所・化鉣コンビナートなどがあるが，本県では 不振であった。

理由として 1. 製品消賽地に遠い，2．地元資本の不 足，3. 地元企業意欲の不足， 4. 各剑山会社に地元関係 が少なかったなどがあげられる。

鉱山の衰退に伴ない，钩山業育成関連産業は急速に縮 小され，組・下請事業者などは他の鉉山地域人移動する。

しかし，加工部师の関連産業は依然その地に定着し， 操業を范けるのが一般である。

\section{束北地方太平洋則，特に海岸地方の大雨の総䚉気候学 的特性}

山下 洋

目的多くの研究者により東北地方太平洋側の海岸地 方が大雨の多発域と指摘されている。しかし総気気侯学 的要素によって大雨の多発域がどのように变るか，その 動態が得られていないのでそれを究明しょうとする。

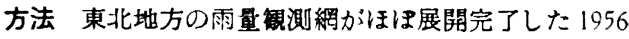
年から 1967 年まで福島・宮城・岩手累の県最多日雨量 が $50 \mathrm{~mm}$ 以上の日を抽出し，諸要素によりその出現動 態を吟味する。

結果 1) 東北地方太平洋側では海岸地方が大雨の多 発域であり，最多雨量が多くなるほどこの倾向は顥漖で ある。

2）西部・中部では前線・雷雨・北西季節風による大 雨が割合多く，東部では台風・低気圧によるるのがかな り多く，特に日雨量 $100 \mathrm{~mm}$ 以上では 81〜90\%がこれ による。

3）南北海面気圧差が大きくなるほど日雨量 $100 \mathrm{~mm}$ 以上の大雨の出現事はまし，出現地は東部に偏る。

4）南北海面気圧差が正で大きくなるほど，東部では 台風・低気王により大雨となる傾向は顥著で，負で大き くなるほど中・西部の前線・雷雨・季節風により大雨と なる傾向が穎著である。

5）大雨出現度数の累単位の年変化は可降水量の年变 化に対応するか，地域別では季穊風季とて月を中心とし て対応か悪い。

6）東奇りの風が最も卓越するときの最多雨量の多発 地点は地形傾斜とは対応していない。

7）北東気流系か门卓越するとき，その温位の低いとき の方が高いときよりも東部で雨量が多くなる。

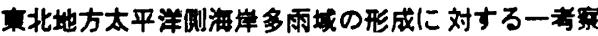 山下 洋}

目的東北地方太平洋側では岩手・福岛罢海岸地方が 
大雨多発域であり、これが多雨域に結びつくが, 総䧃気 候学的特性から，さらになぜそうならねばならないかを 究明する。

方法 従来，動気候的立場から諭じられてきたが，こ こでは熱的安定度の立場から論じ，レーター観測資料・ 海面水温分布・高層気象覞測登料等による事例解断によ り検証する。

結果 従来, 第 2 喠地形性前線・地形性降雨・降水量 に及はす海岸効果等が述へられていて，海岸付近が雨ま たは対流雲の生成域であるかのような概念が提出されて いた。しかし北東気流系にのる気塊か低温であればある 程，海上で熱を供与されて対流雲を生成し，陸上では熱 の供与がないために海岸付近では対流雲の消滅域となる ことか，海岸性紊雨をしたらす「来地」であるというこ とを提唱する。

\section{火山々高の地形分類についての一試案}

水野裕

火山マ䉥の地形分類については従来，分類らしいもの はない。しかし，広大な火山マ簏は，〈わしくみると成 因や形成時期の異なる地形の集合である。そこで筆者 は，岩木・鳥海・有珠・駒々岳の各火山管を調查し，山 簏を橔成している堆積物を分類し，これら各堆積物が くる地形を区分してみた。その結果，山簏を糐成してい るものは従来一般にいわれているような本筫物筫より， むしろ類筫物筫からなる流下堆栍物が多いことを知っ

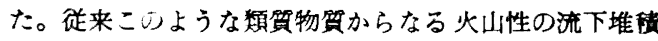
物は“火山泥流”として一括され，はなはだ美の内容 をもち，混乱をまねいている。

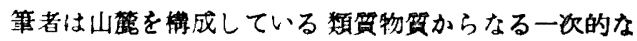
流下堆渍物の地形を その特得から“avalanche 型の火 山岩居流の地形” - “flow 型の火山岩罣流の地形” - “火 山泥土流の地形”の3つに分け，二次的な流下堆稜物の 地形として“火山扇状地”を含めた。

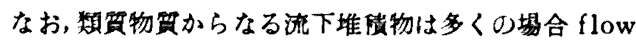
型の火山岩局流 $\rightarrow$ avalanche 型の火山岩屏流 $\rightarrow$ 火山泥 土流の順序で喷出しており，ある程度の規則性がみら る。

\section{明治後期以後におけろ全国の漁造物棈成についで} 山下 克彦

漁業の研究を漁場一漁港一消費地と心関係で分析する 場合には生座対象としての漁場も考然する必要がある。 しかも，漁場を単なる生物資源の伊在としてみるたけで なく，いかなる性格を有する漁業者がどのような蛗源を いかなる手段によって漁擭するかという点から考察する へきであろう。漁場の变化そのものを知ることは筫料の 制的があって不可能なので, 漁獲物の榑成がどう変化し たかということ通して間接的に整理した。

资料は農商䅂省統計，農林省統計を利用し，従来の漁 莱発连の研究を参考にして発展段階を区分した。それ
ぞれの発展段皆における府累別の魚理榑成を考宗した。

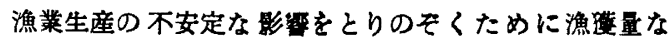
いしは金額つ 3 年の単純平均を算出し，土井氏の修正 Weaver 法によってその魚踵㙛成を求めた。

魚種淵成の等筫性に注目して，地域又分を行うと次の ようになる。

I 功力化の当初より比較的固定したまとまりを有し ており, 主要なメルクマールは A (水産動物) である。 この型には青森と岩手が該当する。

II 宮城から千葉にいたる東北太平洋の諸紫で, 戦前 は B (カツオ), T (マグロ) の槹成において共通であっ たが，戦後は P (サンマ) がそれにかわっている。

III T 型を主要な指䅺としており，東京から棦岡に 到る県で, 大都市の市場を背景に成立した地域である。

IV 采知より以西の太平洋岸の諸累を含み $\mathrm{B} \cdot \mathrm{T}$ の 構成を有し，戦前の段階において形成され，戦後はこれ らの地域のまとまりは消失している。

$\mathrm{V}$ 生産力が低い瀬戸内および九州を中心にした地域 で A.S (イワシ)，h (貝類) の榑成のほかに戦後は W （藻類）が付加されている。

VI 趿力化が最高の段階に達した1935年から， A. M (サバ)， m(アジ）を中心とした指標によって区分され る日本海側南部の福井から島根がこれに該当する。

*1969 年文部省科学研究貫 (地域変化の研究, 代表 者 西村嘉助教授) の一部を使用した.

\section{東北地方の海岸に立地するエ捧について}

渡辺 四郎

卢各種の工場が海岸及び海洋を利用している实態を 調查し，海岸か土場立地に及注す影謷を考察する。海岸 に立地する工場とは仮に「海岸線を持つ市町村に位置す るエ場」と定める。

1 海岸に位置する主な工業地域 大工場が数多く雀 中する地域を工莱地域とすると，東北地方では７地域を 選ふこことができる。各地区の範囲は統計資料を用いる便 宜から，通産省が工場適地調查に際して設定した領域と する。これら 7 地域の工業を概铸すると，食料品工業は 共通に発達する。このほかに化学，鉄鈵，非鉄金属， 紙・バルフ製造業のように大装置を必要とする業種の出 荷額が特に多い。木材，案業部閁もこれについで出荷が 多w。

2 工場立地以前の地形，土地利用 前項にあげた大 装置を必要とする工場は厸い用地を求める。この用地の 特性をみるためにこれら各部門の工場が位置する地域 の, 工場立地以前の地形，土地利用状態を㭘討した。明 治末年測図の 5 万分の 1 地形図をこの際の主な资料とし た。海岸の砂丘，浜堤等の非耕地が第 1 に用地に态てら れる。第 2 に河川改修をした場合の河川跡とそのまわり が工場用地となる。三陸沿掉においてのみ谷底平野の费 耕可能地か门工場制地になっている。港涼を啃筑し，広い 平坦地を利用できる砂浜海席が場用地に選定された事 
情を一般に認めることができる。

3 港湾利用について 海岸の諸工場が港弯を利用寸 る状態を，原材料・製品の搬入・搬出状態から梌討し た。大別すれば搬入搬出とるに港学を良く利用するエ 場，原料被入には港弯を利用するが製品搬出には利用し ない工場およびその逆の工場と 3 種の類型が承められ た。第 1 類型は三陸地方に多く見られる は原材料，市場が共に少ないことを示す。第 2 類型は東 北全般にみられるもので，東北地方を主な市場とし原料 を海路投入する工場と，逆に国の内外にわたる允い地或 を市場とするが，その製品の重量，容量が小さいために， 広い用地だけを求めて東北地方に立地できる工場とがあ る。第3類型は地元資源に主として立脚し，その製品を 広く各地域一出荷する工場である。地元資源が少なくな れば第 1 類型に変る可能性がる。海岸にあっても港弯 がなけれは装置を使用する工場はなく，機成工場等だ けが立地する。

4 七すび 東北地方の海岸に位置する工場の主な立 地要因仙浜堤，河川跡等の公い原野を利用することであ り，ついで，その砂浜海岸に港弯が整備されると，その 港唀を利用して大規模な装置を動かす大工場になるとい える。また地元資源に強く誘因された工場の存在 る大き い。食料品，木材工業等の中小規模工望の多い業㮔には 論及しなかった。

\section{都市のノン・ペイシック産業の従業者諢成によろ中心 地既屈の判定}

$$
\text { 土井 喜久一 }
$$

前提 ジョン・アレクサンターが提唱した都市産業の ベイシック・ノンベイシックという重要な概念をさらに 発展させ，その基準地域を市域からその都活园に拡大寸 れば,ノンペイシック産業は一層呢確な概念となり，加 つ多くの都市について共通の構成を示すと予想される。 また階層の上位の都市は下位階次の固有の都市圈に対す るノン・ペシック産業の他に, 従属する他の下位都市 の都市圈に対するノン・ヘイシック從業者をるっている ので，その分だけノン・ベイシック麾業の規模が大きく なり，構成も㚆化している筈である。

方法 主として都市圈外に商品又はサービスを提供す る産業をぺイシック産業とする。例えは農業・鉱業・局 地需要に応ずる食料品製造を除く製造業・温泉旅館業な そとこれらを補助する貨物運送業・修理業なと。都市图 内の住民の生活的消費需要に応ずる諸産業をノン・ベィ シック産業とする。小売商業の大部分, 産地問屋を除く 卸売業，対個人サービス業の大部分がれに当る。従業 者は両部門とる中心都市だけでなく都市圈内の町村のも のる合計するのが本旨であるか，凟料（昭和 41 年事業 所統計調査報告第 3 卷都市篇）の関係でとりあえず各市 の従業者について分析した。本資料は200 余の鷹業小分 類について事業所数と従業者数を示しているか今回は主 に中分類を用いた。飲食店を除く小売業従業者総数を
100 として衣服・身の迴り品小売業（百貨店を含む），卸 売業，金融保険業などの従業者の比事を計算した。

結果 小売業従業者総数は中心地の規模を表わすのに 適切な指標であること, 同規模の中心地（大都市の衙星 都市を除く)ではノン・ベイシック産業各部門の比率が 近似し，功規模（階層）のちがう都市の間ではこの比 來にかなり明白な段㫮差があることがわかった。これに よって全国の市を一定の基罡にもとついて階層区分を行 なうことができる。今回はこの階層区分試案を発表して 批判を乞い，続いて町村分も合計した都市圈のノン・ベ イシック産業の規模と柫造およびベイシック鷹業との従 業者数比（B/N 比）の問題に進む予定である。

\section{全国新閔の配布地域}

原田 栄

わが国における新聞産業の特色の1つは，全国新開の 存在である。全国新闑は，同一資本の新聞社が，幾つか の発行地から同一題字の新聞を印别発行し, 地域を区切 って全国的配布している形態である。これら全国新闻の 発行部数は，それぞれ5 50 万部にも及ひ外国の新間に比 すれば成到的な部数を示している。

今回は，この全国新聞の配布地域をとりあげ，その模 造を明らかにした。その結果は，（1）全国新聞 A · B 2 社は, 東京·名古屋·大阪・北九州加発行し, ほ涂同 様の配布地域を有している。C 社は, 東京・高岡・大 阪・北九州で発行しており, やや前 2 社とは異なる。 （2）都道府県では，島根県が大阪・北九州に2 分され, 三重・静岡県の一部が分割されている。（3）1世带あた りの全新䟚配布部数をみると, 関東・中部・近䜯・九州 北部なぞ新郮発行地に高くなっている。（4）さらに，全 圆新門の 1 世带あたり配布部数の分布をみると，関東・ 近掝・山口・福岡などが高く，東北・四国・九州南部な ぞか低い，印刷発行地加ら遠さかるに従って一種の圈棬 造がられる。(4)また，地方新闒の 1 世带あたり配布 部数は, 前の場合とは逆に, 遠距離地域の青森・富山・ 石川・福井などが高く，近距蜼地域の埼玉・千葉・和歌 山・奈良などでは低い結果があらわれている。(5) 全国 新閁と地方新聞の1世带あたり配布部数の組合せから， 配布類型をつくってみると，全国新跅優位地域は関東.

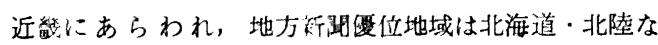
ぞ，中間型は，全国僈位地域の外侧にでてくる。その他 地域沬全配布部数が少ない地域やフロック新泡（数県を 配布地域とする）地域が多い。（6）以上の考祭をまとめ る意味で，刷出しの遅速をとらえると，東京・大阪を中 心とした時間距離との関連での配布图構造が明確に指摘 できる。北九州・名古屋の場合はさほど明確にはでてき ていない。

台湾西岸の站州の変化と日本の砂州 茂木 昭夫 湖湖道に面する台湾西岸には，3つの大規模な砂州 
が発迲しているが，1891 年頃から 1962 年頃に至る約 60 年間に著しい南への移動か生じた。演者はこの大規模な 砂州の变化機構を旧日本資料と最近の中華民国海図との 比較から考察し，日本の砂州をこの現象と対盟させ乍ら 合わせ考察した。結果は下記の通り。

(1) 砂州は何れる北西㑡か; 侵蝕され，南西又は南側か～ 堆積を受けている。その結果砂州は南西方及は南方に移 娌した。

(2) 砂州は以前よりも激湖水道の中へつき出してきた だけでなく，砂州の方向か以前よりも激湖水道に対して 大角度をとるようになった。

(3) 砂州の侵蝕されたあとには，10〜20 m の侵触面が 形成された。

(4) 侵触面上にはしばしば以前の砂州の痕跡が地形と して残される。このことから以前の砂州の位置を推定す ることが可能なことがある。

(5) 古い矽州を新しい矽州が切って生ずる場合, 新し い砂堤の背後にこれを斜交して古い砂堤か残る。これは 以前の砂州の位置を知るよい手がかりである。

(6) 砂州の先端冲には通常深みをへだてて砂堆が形成 される。

(7)このような砂堆は，砂州の移動に際して新しい砂 州の先端部に变る場合が多い。

(8) 沘湖水道の砂州は北東一南西方向の卓越風によっ て起される沿岸流か，水道内の強い瀬流と合して形成さ れたものと思われる。

(9) 砂州海岸に対する傾きの变化は，沖の方からの 波に対して海岸が直角になろうとするためであると思わ れる。

(111)過去 60 年間に生じた砂州の変化は，北端に注ぐ渴 水洷による沿岸流の摄乱に㷎因すると思われる。

(111) 日本の代表的砂州である野付崎 6 三保崎 6 過去数 10 年の間に殆んど变化をしていない。

(10) 野付绮は 野付水道の中央に達して南からの波を受 けるようになった為移動が stop した。

(113 三保崎は砂州がのひてて酸河弯の深海盆に逹した為， 成展が止った。

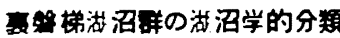

加藤 武婎·会田 徳在

裏慗梯地域すなわち磐梯火山の北方斜面には大小多数 の湖沼が分布する。そのうちの，いくつかの湖群は五色 沼と称せられて一般に知られている。われわれは，五色 沼を中心にこれらの湖沼の代表的なbのについて，1967

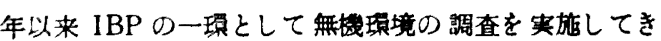
た。その結果のひとつとしてこれらの湖沼は水䓄から 考えて5群に分類することができることを知った。

I 赤泥沼系：赤泥沼，緑沼，もうせん沼，瑠垴 沼, 青沼

(特解) $\mathrm{pH}=3.2 \sim 4.8$ ，

$$
\left\{\begin{array}{l}
\mathrm{SO}_{4}^{2-}>\mathrm{Cl}^{-}>\mathrm{HCO}_{3}^{-} \\
\mathrm{HCO}_{3}=0
\end{array}\right.
$$

II. 五色沼系：弥六沼，父沼，母沼，楖沼，弁天 沼, 竜沼, 深泥沼, 赤沼, 昆沙阿沼, 电沙阴上 沼

(特微) $\mathrm{pH} \doteqdot 6, \quad \mathrm{SO}_{4}{ }^{2-}>\mathrm{Cl}->\mathrm{HCO}_{8}{ }^{-}$

III. Uぼり沼系：工夫沼, ひぼり沼 (特碳) $\mathrm{pH} \fallingdotseq 7, \quad \mathrm{SO}_{4}{ }^{2-}>\mathrm{Cl}->\mathrm{HCO}_{8}-$

IV. 川上青沼系：川上上沼，川上青沼 (特徽) $\mathrm{pH} \fallingdotseq 7, \quad \mathrm{SO}_{4}{ }^{2-} \doteqdot \mathrm{Cl}^{-}>\mathrm{HCO}_{3}{ }^{-}$

V. 京カ林系：京ガ森 No.1〜No. 5 (特街) $\mathrm{pH} \fallingdotseq i, \quad \mathrm{SO}_{4}^{2-} \fallingdotseq \mathrm{HCO}_{3}->\mathrm{Cl}-$

つきに,これらの湖沼のうち竜沼については，年間を 通じての制測を行ない，水温およひ化学成居の発達か～ 瑟められないことを知った。この湖水の主溶存成分は $\mathrm{CaSO}_{4}$ である。

楖沼は五色沼湖群のひとつではあるが，竜沼と異な り，夏季，冬季にそれぞれ水温が成局し，秋季に循環す る。いわゆる温带湖の特微を示す。

竜沼，楖沼において，水中照度の垂直分布を覞測した が，深度 Dにおける照度 Iのあいたには $\mathrm{I}=\mathrm{I}_{\mathbf{0}} \exp$ $(-\alpha \mathrm{D})$ か成り立つ。ここに $\mathrm{I}_{0}, \alpha$ は各湖沼に特有な 定数である。1969 年 11 月の钼測では, 吸収係数 $a$ の值 は竜沼・楖沼において，それぞれ0.230，0.289 であっ た。

\section{宫城悬松川に見られる敢性强度の変化について}

前田 信寿

松川は藏王火山のお釜周辺から源を発する濁川と，屏 風画北西方から源を発する澄川との合流点から，阿武隈 川の支流白石川に合流する間である。古来この水系は荿 王火山の活動にともなって，その水贸に変動があったよ うであるが，その原因は濁川の方にあったのである。昭 和 4)年末頃からもまた濁川は强酸性化し，それに伴っ て松川う悪貿化したのである。すなわち濁川，澄川の合 流点における昭和 39 年までの $\mathrm{pH}$ は 4.5 であったが， 昭和 42 年には 2.5 以下を示し， $8 \mathrm{~km}$ 下流の不趿用水 取入口でも，11 km 下の大除第二用水取入口でも 3.0 に は達しなかった。この影䇾は白石川に合流後にも及んで いるのである。昭和 44 年に入ってからはや〉 $\mathrm{pH}$ は上 年したが，年末からはまた僅に低下しているようであ る。この原因である濁川上流に溥出した所謂振子沢温泉 を調查し，又各地点から試水を採取して化学分析を行っ た。その結果新温泉は蒸発残渣か;甚しく多く(等張泉)， 又 $\mathrm{SO}_{4}{ }^{2-} p \mathrm{Cl}^{-}$も渚しく多く(硫酸塩泉)， $\mathrm{pH}$ 低下の 主因はこの耐者にあることを知った。更に鉄イオンの含 量も落しく多い。濁川に合流する澄川，秋山沢は濁川よ りも水量が多く，どちらも中性なのて $\mathrm{pH}$ は上年する管 であるが，発西用に用いられているため松川の上流では ほとんど濁川そのちのと大美なく，下流では嚾に酸性が 弱くなった。酸性が弱くなり $\mathrm{pH}$ が上甼するに伴なって 
㙁類や硫酸イオン，塩来イオンの含量は減少した。この 水を利用する水田の土壦は酸性化と鉄イオンの流入によ

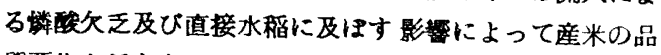
筫悪化と低收を招くわけであるか，精農家は憎習的に施 肥法によっでれを防止していた。なおこの調查は横山 委, 小関恭及び大河原土地改良事務所の御協力御援助 によったので苝して感謝の意を表する次第である。

\section{三戸付近の㷉丘地形と地殻显動}

\section{新户部 芳}

目的 馬淵川下流特に三户付近り段丘棧成について綸 ずる。この地域については中川久夫・大池昭二（1966） らの研究がある。筆者は主として段丘堆皘物から本地域 の地殾運動について吟味する。

方法 実地跨查と 3,000 分の1地形园の作業により対 比検討した。

結果 1. 下名久井〜三戸間の左岸段丘堆栍物は斗賀 粉層を基盤としている。

2. 及右岸は名久井岳の基盤を輠成する和田砂岩層 (新第三紀) から成りたっているが第四紀段丘堆皘物 発達は顥著でない。

3. 下名久井〜三戸間の左岸は浮石流段丘から桠成さ れているか＼cjkstart右岸には殆んどみられない。

4. 然し上流の支流猿辺川，熊原川には浮石流段丘い， 発達が模式的である。

5. 以上の事実から堆栍物の非対标性を次しように判 断した。

イ, 十和田火山に起源を方つ十和田浮石流は支流は 勿論，馬淵川下流の河谷を地く充てんした。

ロ，その後左岸部の隆起運動により㑯動的作用が加 美された右岸部の浮石流堆榬物か：削制された。

八この事は本流の侵食力より傾動的運動か㧧く動 いたものと思われる。

二，従ってこの地域の段丘搆成は一兒同高度から同 一段丘と見做し腾ちであるが尖は以上の事䒠か ら右岸は侵食段丘, 左岸は堆栍段丘と罗る事か 妥当である。

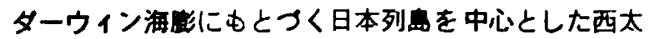 平洋の榡造発社}

茂木 昭夫

フィリピン海を中心とする西太平洋の構造地形を解杉 している間に，演者は西太平洋の棈造発達について或る 考えをるつに至ったので，こっに作業仮説として提唱し たい。演者の之は最近の大洋底拡大説，マントル対流説 の立場に立つちので，又メナードのダーウィン海脚就を 拡張したものである。

フィリピン海は東日本島弧系と西日本胳弧系によって 㣣まれこっには両側岛弧にほう平行な九州一バラオ海 嶺, 紀南海山系一西マリアナ・トラフなどがあるが，北
西隅にばん居する大東海嶺群は，これらとは異質な唯一 の東西方向をもつ。大東海嶺群と近接大陸・島弧との間 には全く関連を見出すことはできない。大東海嶺群は頂 部に瓜い平坦面を有し，こ〉に屹立する 2 小島は琩瑚石 灰岩からなり，ギョーと全く同じ性貿と考えられる。こ の東方の四国海盆南部の深海丘は同栐な東西方向をもっ た ridge で, 伊豆一小笠原海溝とマリアナ海溝の間に㔖 つこんでくる中央太平洋海嶺と大東海嶺群を結びつけて いる。以上の事から演者は大東海嶺群は中央太平洋海领 すなわちダーウィン海慖の一部であると考える。伊豆一 マリアナにおける中・深発地霞はちょうどこの部分で久 けており，heat flow もこれに沿うて低いことは，この 考えを支持する。以上U尔から，西太平洋においては， ターウィン海膨がフィリピン海まで漼し，こ〉から地熱 流が漂き上り，南北に流れていた。その為とくに東西方 向の大陸縁辺に造山運動を生じた。白堅紀以後多分第三

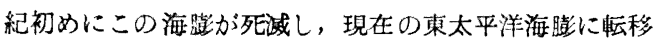
し，地熱流は西へ向って流れるようになった為これれの 真向いに当る南北方向の岛弧を形成した。目本列島の白 㤠紀以前す各造山運動々新第三紀におけるグリーンタフ 地向斜の形成以後に見られる造山運動の方向の大転換 や，同時期に生じた日本海の形成（日本島の漂移）など の大変革は，海膨の転移々時期・方向において符合す る。又西南日本海溝などの埋れた古い海溝の存在の説明 も可能である。

\section{東ネバールおよび北東インドにおけろ環境としての地 形の役割}

米地 文夫

1970 年 1 3 月, ネバール王国学術韵查隊（長井政太 郎隊長：山形新明・山形放送主催）ひ一貝として東ネ パールおよび北東インド（特にダーシリン地区）の調查 を行った。従来この地域の自然環境としては，筑候・植 生が中心にとりあげられ，地形は单に活のみが問題々 されがちであったがこの報告では小〜微地形の環境と してい役割の大きさについて4つひ例をとってのへる。

(1) カトマントゥ盆地の地形的特性：この盆地は, 未 パールの山岳地带の中では例外的に平坦で，いわゆるサ フ・ヒマラヤにおける政治・経斉・文化の中心となって いる盆地である。こり盆地はとマラヤから流下する各河 川とは别個の, 独立した水系に属し, 湖成段丘が広い面 䅡を占める。こひような特性は, 永地南部の石灰岩地带 の存在による所が大きい。

(2) 市場集落の地形的位置：ネバール東部や北東イン ドのハサール策落の立地には，単なる交通上の要地であ るのみならず，地形的特性のよく活かされたものが多 い。ここでは，尾根上のチョウタラ，河谷底のトリス リ・バサール，的状地上のダラン，の3例をあげ，その 立地と地形との関係について述へる。

(3) シワリーク丘陵の役割：川喜田 (1955)によれば， この丘陵は垶和としての役制を果したとされているか， 
むしろこの丘陵をほとんど久くシッキムなどの場合の 方か，かってその奥の地域の隔䎦性を強めていたと考え る。

(4) 地形と水害とU関保 : ダージリン・カリンボン地 方は 1968 年 10 月の東ヒマラヤ水害の際，大きな被害を
蒙った。傾斜 30 度にも達する斜面を段々畑に化するネ バール式の農業の漫透にとるなって，この種の災害が重 大化している。また，深い横谷をなすティスタ川の岸に 交通路が開かれていたがここれに沿う集落も悲惨な炎禍 にみまわれた。

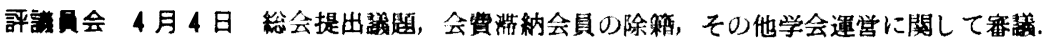

\section{0 年度給会 4 月4日 米北大学教善部において}

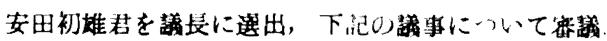

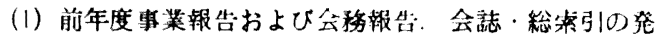
行, 学術大会, 翰事会, 11 年度文部省科学研究費補助 金（刊行助成金）山父付，公貝動静（会員現況824名）を 報告，以上承㒄，（2）前年度収支決算および会計監查を
報告。これを承諗，（3）当年度事業計画およぴ予算策の

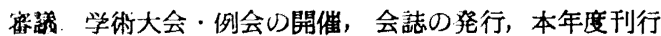
助成位ひ申热およひ予算案について説明，以上承認. (1)

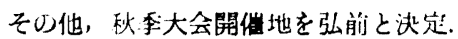

\section{0 年度春季学術大会 4 月 4.5 日 東北大学教厗部において}

\section{研究発表 15 参加者約 611 行}

巡娭4月6日（月） 9.00 作恶温㲾出発，二ッカ ウイスキー工場を見学. ウイスキーの製造工程の見学の 俊, 仙台工場が作並に立地した経繰, 他の同社工場との 関釈，原料およひ製品の入荷地域と出荷地域，從業貝の 通勤範团等について説明・質疑・応答があった，その後 白沢・野中をへて二口陕谷ひ翇闰岩にいたる，途中，㕕
瀬川および名取川の段丘地形や付近ひ 丘陵地形について 詳しい説明があった，不動滝にもどって冝食．そい後秋 保・浾石をへて釜房ダ幺に至る。 ダム建設の目的，建設 が地汇川崎町に及怆た影響，水没に伴なう補腹問題に ついて説明があったままた川崎町長期開発計画について の紹介があった，茂庭・鈎取・八木山・東北大工学部を へて仙台駅で解散 (15.40). 参加者 25 名.

\section{幹 事 会}

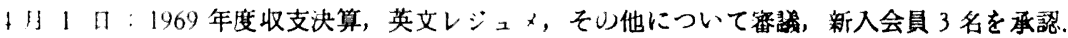

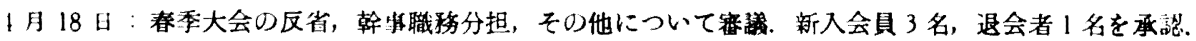

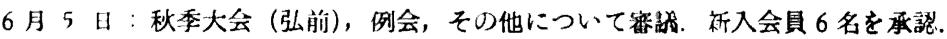

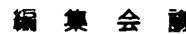

5月 4 日：編集幹事事務分担，英文校貦凹件，22 巻 3 号の編重.

5月 22 日：22 巻 3 号の編菓, 英文校獖について.

6 月 5 日: 22 巻 3 号の編集.

\section{新入 会 \\ 他田司 \\ 大井 兼- \\ 梶野修平 \\ 小家 武栄 \\ 田村 勝让 \\ 中一淠子 \\ 八月I 急明 \\ 低本礼㣂 \\ 三河 敬二: \\ 八离 邦夫}

\author{
(徳岛大学学生) \\ (立正大学学生) \\ (東北大学大学院) \\ (年京教育大学大学院) \\ (同左) \\ (官城教育大学学生) \\ （位正大学学生） \\ （佁岛大学大学院） \\ （徳息大学学生） \\ （東北大学大学院）
}

